\title{
TRACERÍAS OLVIDADAS: EL CLAUSTRO GÓTICO DE SANTA MARÍA DE SASAMÓN*
}

Cristina Tuimil Fernández

Universidade de Santiago de Compostela

Data recepción: 2018/06/09

Data aceptación: 2018/12/19

Contacto autora: cristina.tuimil@usc.es

ORCID: https://orcid.org/0002-6112-239X

\section{RESUMEN}

Tradicionalmente, el claustro del conjunto burgalés de Santa María de Sasamón ha sido datado entre finales del siglo XV y principios del XVI y adscrito a la autoría de Juan de Colonia. A lo largo de estas páginas se intentará demostrar que este recinto fue comenzado muchos años antes de la llegada del arquitecto alemán a la Península y que su apariencia actual se debe, en realidad, a dos campañas constructivas distintas en estilo y distantes en el tiempo. Con ello se pretende recuperar para la Historia del arte medieval hispano un claustro del más puro gótico radiante.

Palabras clave: claustro, Sasamón, gótico radiante, siglo XIV, Burgos

\section{ABSTRACT}

The few authors who have devoted their attention to the cloister of the former collegiate church of Santa María de Sasamón (Burgos) have dated it to the period between the late 15th and early 16th centuries and have attributed its construction to Juan de Colonia. In these pages I will attempt to demonstrate that work on this building began many years before the German architect's arrival on the Iberian Peninsula and that its current appearance is the result of two different building campaigns. The aim in doing so is to identify a cloister of the purest Rayonnant style as part of the history of Spanish Gothic architecture.

Keywords: cloister, Sasamón, Rayonnant style, 14th century, Burgos

1. El claustro de Santa María de Sasamón: estado de la cuestión

El conjunto burgalés de Santa María de Sasamón ha permanecido olvidado por la historia del arte gótico hispano'. Un incendio sufrido durante la Guerra de la Independencia, que afectó especialmente a la parte noroeste de la iglesia y al claustro, causó la pérdida de toda la documentación que custodiaba el templo relativa a su fundación y a su historia, como así lo manifiesta un documento de 1816 conservado en el Archivo Diocesano de Burgos². Este vacío documental ha dificultado la reconstrucción de la historia edilicia de la iglesia y ha sido, probablemente, la causa principal de que su estudio en profundidad no haya sido llevado a cabo hasta el momento ${ }^{3}$.

Con todo, los escasos estudiosos que le han prestado atención parecen coincidir, en términos generales, en que el conjunto segisamonense es el resultado de una serie de campañas constructivas sucesivas. Así, su fábrica se habría dilatado en el tiempo desde el reinado de Alfonso VIII hasta el de los Reyes Católicos (fig. 1). La iglesia se habría iniciado a finales del siglo XII, y de esa 


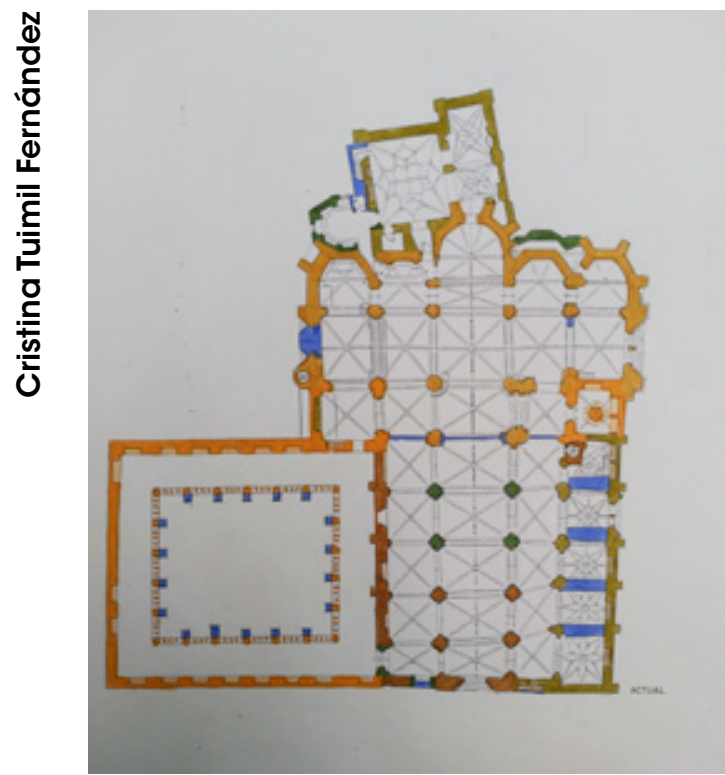

Fig. 1. Santa María de Sasamón. Planta. Extraída de Andrés Oroño Díaz y Miguel A. López Miguel, Santa María la Real de Sasamón, 18

primera campaña se conservaría hoy únicamente el cuerpo de naves ${ }^{4}$, la fachada occidental y el primer cuerpo de la torre. Una segunda fase, que se podría fechar en torno a las primeras décadas del siglo XIV, abarcaría la construcción del actual crucero y la cabecera que, con toda probabilidad, vino a sustituir a una primitiva ${ }^{5}$. A esta campaña correspondería también la labra de la portada meridional del crucero, la más importante del templo y por la que hoy se accede a su interior. Por último, todos estos autores señalan una importante intervención entre finales del siglo XV y principios del XVI, cuando se habría añadido a la iglesia una nueva nave colateral en el lado de la epístola, un segundo cuerpo a la torre -cuyo último tramo sería agregado ya en el siglo XVIII- y, adosada a la cabecera, una sacristía acompañada de dependencias canonicales. En este momento se labraría, además, una segunda portada en el lado sur de la iglesia, situada más a los pies que la primera. La fecha de este empuje constructivo vendría confirmada por una inscripción que todavía se conserva en una cartela situada en la parte superior de dicha portada. En ella puede leerse: "esta portada e capi/llas se acabaron a/ año de mil quinien/tos cuatro años". Es en esta tercera campaña en la que encuadran todos ellos

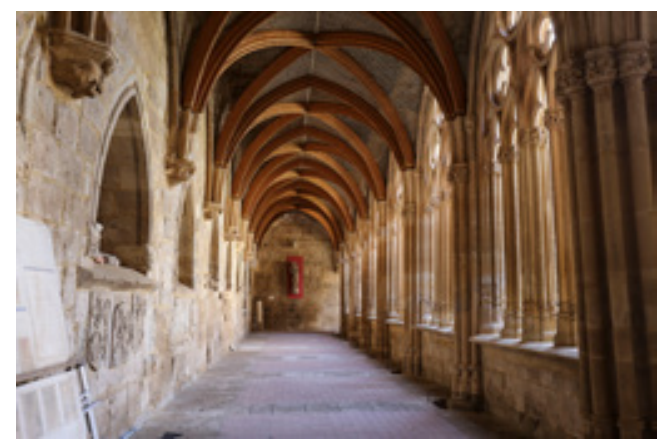

Fig. 2. Santa María de Sasamón. Claustro. Vista interior de la panda occidental desde el ángulo suroeste. Fotografía de la autora

la construcción del claustro adosado a la nave del evangelio.

Si bien concuerdo, a grandes rasgos, con la definición de estas fases en su conjunto, considero que la datación del recinto claustral debe ser minuciosamente revisada.

Este claustro se dispone contiguo al flanco norte de la iglesia y presenta una planta irregular, casi cuadrada, con una proporción de cinco tramos en sus lados menores (norte y sur) por seis en los mayores (este y oeste). En el interior, los muros perimetrales se encuentran horadados por una sucesión de arcosolios y los ventanales que miran al patio están decorados con elegantes tracerías (fig. 2). La cubierta actual ha sido levantada en una intervención reciente emulando el que habría sido el aspecto de las bóvedas originales, desaparecidas tras el incendio. Hoy se accede a él por su ángulo sureste, a través de una puerta abierta en la conocida como capilla de los Santos Juanes -ubicada al norte del primer tramo de la nave-, a modo de solución improvisada tras los desastres causados por la guerra. Sin embargo, a lo largo de su historia el claustro contó al menos con otros dos accesos desde la nave norte de la iglesia -es decir, en su panda meridional-, ambos inutilizados tras los graves daños que sufrió esa parte del edificio.

Fue ese claustro, el incendiado y arruinado (fig. 3), el que generó la tradición de estudios que tradicionalmente han venido datando su construcción entre los siglos XV y XVI. En concreto, fue durante los siglos XIX y XX cuando esta teoría cobró forma y se consolidó como la 
única vigente hasta nuestros días. El autor que firma en 1844 como "S. de la C" parece haber sido el primero en identificar el claustro como una de las ampliaciones de la iglesia en el siglo $X V l^{6}$. Años más tarde, en una conferencia leída en el Ateneo de Madrid en 1899, Eloy García de Quevedo y Concellón lo calificaba como "un ejemplar primoroso del arte del siglo $\mathrm{XV}^{\text {"7. }}$. Fue Vicente Lampérez, en 1904, el que añadió a esta datación tardía la atribución de su labra a los talleres de los Colonia y los Siloé, con los que identificaba su estilor. Finalmente, Luciano Huidobro, en 1911, lo fechó de nuevo en el siglo XV y catalogó sus esculturas como "de un marcado sabor alemán"`, idea que repitió Teófilo López Mata en su parca descripción del claustro en la que reflejó, además, el estado de ruina y abandono en que se encontraba todavía en $1952^{10}$. En 1955, Matías Martínez Burgos, asumiendo la atribución propuesta por Lampérez de la autoría del claustro a un discípulo de Juan de Colonia, se inclinó por el propio maestro alemán, del que destacó "su sobriedad frente a la exuberancia de su hijo Simón" ". Desde que el historiador burgalés se hiciera eco de la opinión de Lampérez, los únicos estudiosos que prestaron cierta -aunque mínima- atención al claustro fueron el párroco de la villa, don Alejandro Orive Salazar, que dejándose llevar por el amor que sentía por su iglesia calificó el claustro de "obra maestra y mimada de Juan de Colonia"12, y Salvador Andrés Ordax, que en su pequeña monografía sobre el crucero de Sasamón presenta de forma superficial el conjunto de la iglesia y el claustro, al que encuadra de nuevo a finales del siglo XV o principios del XVI y relaciona con la mano de los Colonia ${ }^{13}$.

Este desinterés se hace aún más extraño teniendo en cuenta que en los años 1996 y 1997 se llevaron a cabo unas obras de restauración del conjunto claustral, que permanecía en estado semiruinoso desde la época del incendio. En esta intervención se procedió a demoler una cubierta de madera existente -levantada, según el citado párroco, a modo de solución provisional en el año 193014- para colocar una nueva techumbre de madera y chapa perforada que protegiese debidamente el recinto de las inclemencias meteorológicas. Además, se reintegraron las tracerías, rellenando y reponiendo los diferentes elementos arquitectónicos parcialmente perdidos (basas, ca-

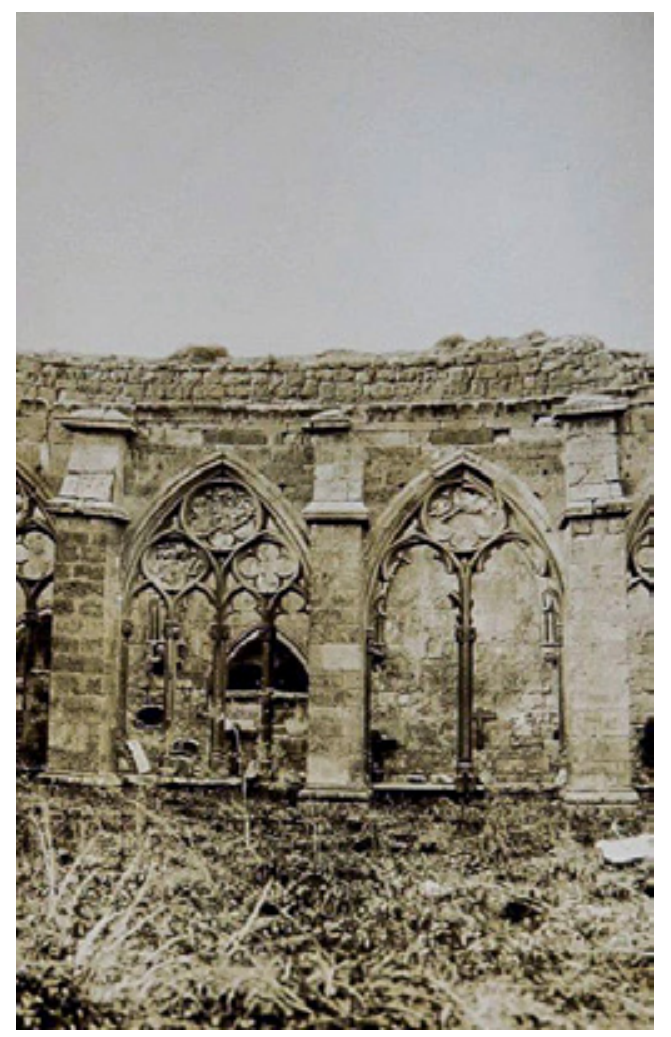

Fig. 3. Santa María de Sasamón. Fotografía de una postal antigua (sin autor ni editorial) que demuestra el estado de ruina en el que se encontraba el claustro tras el incendio. Fotografía de la autora

piteles, maineles y lancetas), se desmontaron los paños desplomados para colocar de nuevo sus elementos y asegurar su estabilidad y se ejecutó un nuevo paso de salida al jardín en el centro de la panda norte, con la consiguiente creación de dos anacrónicos capiteles pinjantes ${ }^{15}$.

Las observaciones del director de la intervención arqueológica desarrollada en paralelo a esta restauración siguen la misma línea de los autores anteriores, defendiendo además una fecha posterior a 1444 para el comienzo de la empresa ${ }^{16}$. Esta postura la respaldaron, también sin sentido crítico, los autores de la guía más reciente de la villa, Isaac Rilova y Jesús Simón'7 , a la vez que insistieron en la autoría del artista alemán. Sólo los arquitectos Andrés Oroño Díaz y Miguel A. López Miguel, autores de un estudio técnico sobre Santa María de Sasamón llevado a cabo en el año 1992 -así como de la memoria final de la citada 


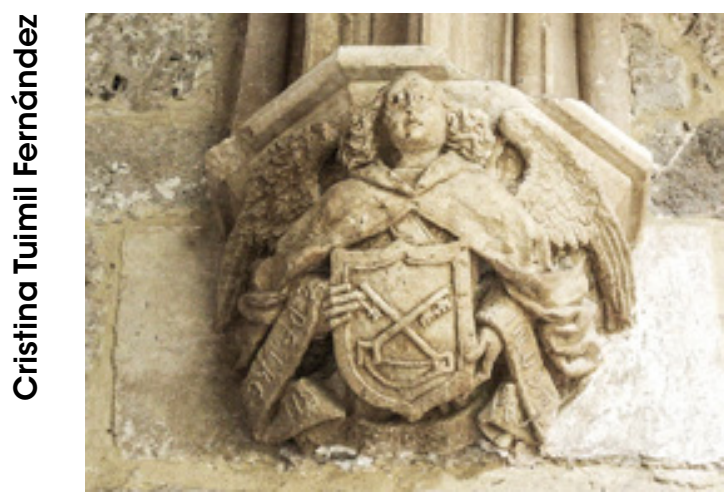

Fig. 4. Santa María de Sasamón. Claustro. Detalle de una ménsula decorada con un ángel que sostiene un escudo con las armas papales. Siglos XV-XVI. Fotografía de Marina Garzón Fernández

restauración en 1998-, parecen haber dudado de la atribución de este claustro al siglo XV y sobre todo de que Juan de Colonia hubiera sido su artífice, cuando escribieron: "en el siglo XIV se construye el claustro procesional (...) Se atribuye, sin base, a Juan de Colonia" ${ }^{18}$. Sin embargo, sus opiniones sobre el claustro resultan contradictorias, pues en otro capítulo afirman que el claustro es obra de "hacia la mitad o el segundo tercio del siglo XV, según la escuela de los Colonia o quizás por ellos mismos"19.

En definitiva, desde que los primeros historiadores de época moderna adscribieran el claustro de Santa María de Sasamón a la escuela -o autoría- de Juan de Colonia, esta idea se fue consolidando hasta convertirse en una verdad incontestada. Quizá la idea de que una familia de la talla de los Colonia hubiese dejado su impronta y su prestigio en un edificio envuelto en el misterio como el que nos ocupa, o quizá un exceso de confianza depositada en el criterio de estos clásicos autores, hicieron que nadie intentase replantearse siquiera la veracidad de estas afirmaciones.

Sin embargo, cuando Vicente Lampérez calificaba el claustro de Sasamón de "gótico alemán" veía el patio cubierto de escombros y plagado de maleza (véase fig. 3) y dirigía su mirada hacia las ménsulas de los muros sobre las que se había apoyado la bóveda desaparecida tras el incendio (fig. 4). A mi juicio, hubo de ser precisamente este hecho el que le llevó a datar el claustro en el siglo $\mathrm{XVI}$. Con todo, ya el propio Lampérez advertía en

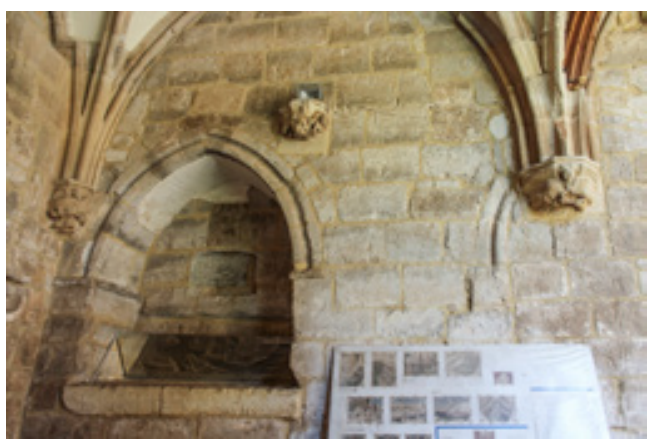

Fig. 5. Santa María de Sasamón. Claustro. Detalle de un arcosolio de la panda oeste tapiado por un arranque de la bóveda. Fotografía de la autora

las tracerías "la pureza" del gótico de los inicios. $Y$ es que esas tracerías tan propias del gótico radiante no podían haberse diseñado tan tarde.

En el presente estudio intentaré rescatar del olvido una obra de singular calidad como es el primitivo claustro de Santa María de Sasamón y demostrar que no se puede adscribir ni a la época ni a la autoría que hasta la fecha se había creído -o querido creer-, sino que su construcción se llevó a cabo al menos cien años antes de que Juan de Colonia hubiese nacido. Me valdré para ello de un análisis formal y estilístico, cruzado con los escasos datos documentales conservados y las circunstancias históricas que vinculan a Sasamón con otros conjuntos.

\section{Un proyecto truncado, una atribución infundada}

La adscripción de todo el recinto claustral segisamonense a los siglos XV y XVI es, a mi parecer, más que discutible. Esta datación tardía parece derivar del escaso protagonismo que los citados historiadores han concedido a los arcosolios que componen los muros de cierre y a las tracerías que decoran los ventanales. Sin embargo, a diferencia de las bóvedas, ambos elementos permanecieron en pie tras el incendio (véase fig. 3) y serán claves para comprender el auténtico proceso constructivo de este claustro que, como intentaré demostrar, es en realidad el fruto de dos campañas constructivas distintas en estilo y distantes en el tiempo.

En mi opinión, el perímetro mural y el conjunto de tracerías forman parte de una empresa anterior 
a la construcción de las bóvedas, que habrían sido añadidas más tarde. Es probable que el ambicioso proyecto original se hubiese visto frustrado por alguna razón de modo que, si los muros de cierre y el cuerpo de ventanas habrían llegado a rematarse, quizá la cubierta no contó con la misma suerte, habiendo tenido que optar por una techumbre sencilla -probablemente de madera- que funcionase como solución provisional20. El claustro debió permanecer en este estado durante largo tiempo hasta que se planteó una nueva actuación en él y se proyectó una nueva cubierta. Tampoco es de descartar que este hubiera contado con una bóveda desde un primer momento, que habría sido remplazada y mejorada en esa empresa que dio lugar a las múltiples intervenciones que el conjunto conoció en los siglos XV y XVI y que ¿por qué no? pudieron haber sido encargadas a artífices formados en el taller burgalés de los Colonia21. Fue por aquel entonces cuando se realizaron los apeos de los muros acompasando los arranques de los nervios de los ventanales para poder lanzar desde ahí las bóvedas ${ }^{22}$.

Como ya he señalado, la escasez documental obliga a basar cualquier hipótesis fundamentalmente en un análisis visual. Creo por ello que la observación pormenorizada de la estructura y el vocabulario arquitectónico y formal del claustro de Sasamón permitirá confirmar la realidad de esas dos etapas constructivas.

La principal evidencia que sustenta esta teoría reside en el mal encuadre existente entre los arranques de las bóvedas y la fisonomía general del claustro. Esta es una particularidad que no solo se aprecia en la panda sur, condicionada por las exigencias del muro norte de la iglesia en el que se apoya, sino también en las tres crujías restantes. Los arquitectos Andrés Oroño Díaz y Miguel A. López Miguel, antes citados, observaron las mismas incoherencias estructurales, pues resaltaron que:

La tracería de sus arcos es de una gran elegancia y bella labra, no así la correspondencia de sus bóvedas nervadas no sólo con contrafuertes del viejo muro norte de la iglesia en el cual se apoyan, sino tampoco con los nichos funerarios alojados en el espesor de los muros restantes que lógicamente debieron ser realizados posteriormente a la construcción del claustro ${ }^{23}$.

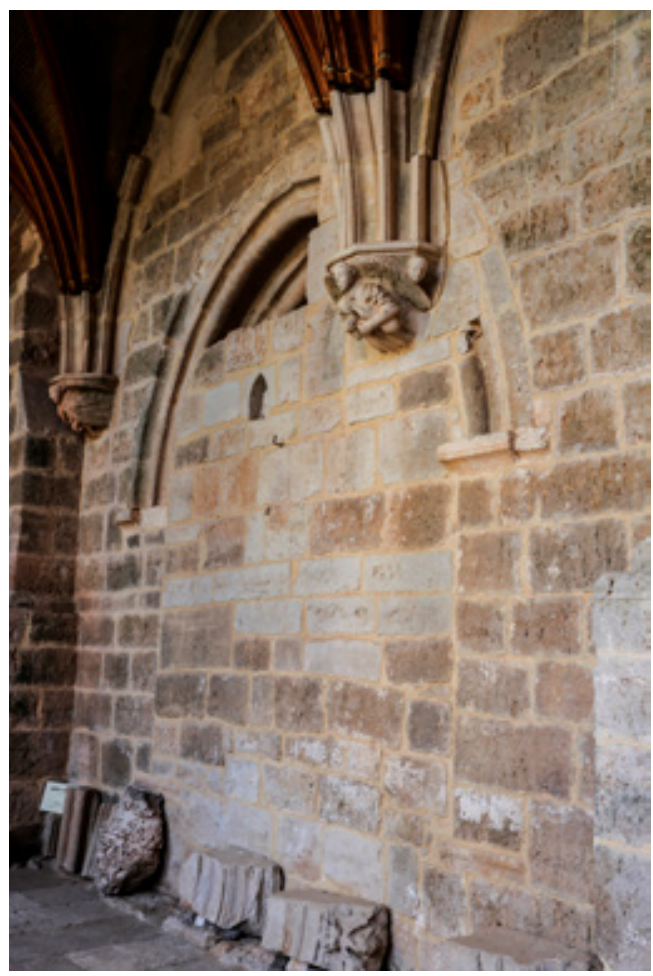

Fig. 6. Santa María de Sasamón. Claustro. Puerta primitiva de acceso al claustro tapiada por un arranque de la bóveda. Fotografía de la autora

A pesar de que estos arquitectos no parecían tener clara la datación del claustro, su análisis estructural puede considerarse del todo fiable. Sin embargo, para no enfrentarse a las contradicciones que esas irregularidades que ellos advertían presentaban con respecto a la historia establecida desviaron la atención hacia los arcosolios, a los que hicieron responsables de dicha incoherencia. No obstante, a mi juicio estos sí forman parte del diseño original de la obra por varias razones que se estudiarán con detalle en el próximo apartado. Lo que parece haber sido un arcosolio en la panda oeste, tapiado hoy por una de las ménsulas, vendría a confirmar su preexistencia con respecto a las bóvedas (fig. 5) ${ }^{24}$.

También se pueden observar alteraciones en el conjunto de accesos que han comunicado la iglesia y el claustro de forma sucesiva. Es probable que la puerta que formaba parte de la primitiva fábrica de la iglesia, hoy tapiada para poder apoyar sobre ella el arranque de una ménsula 


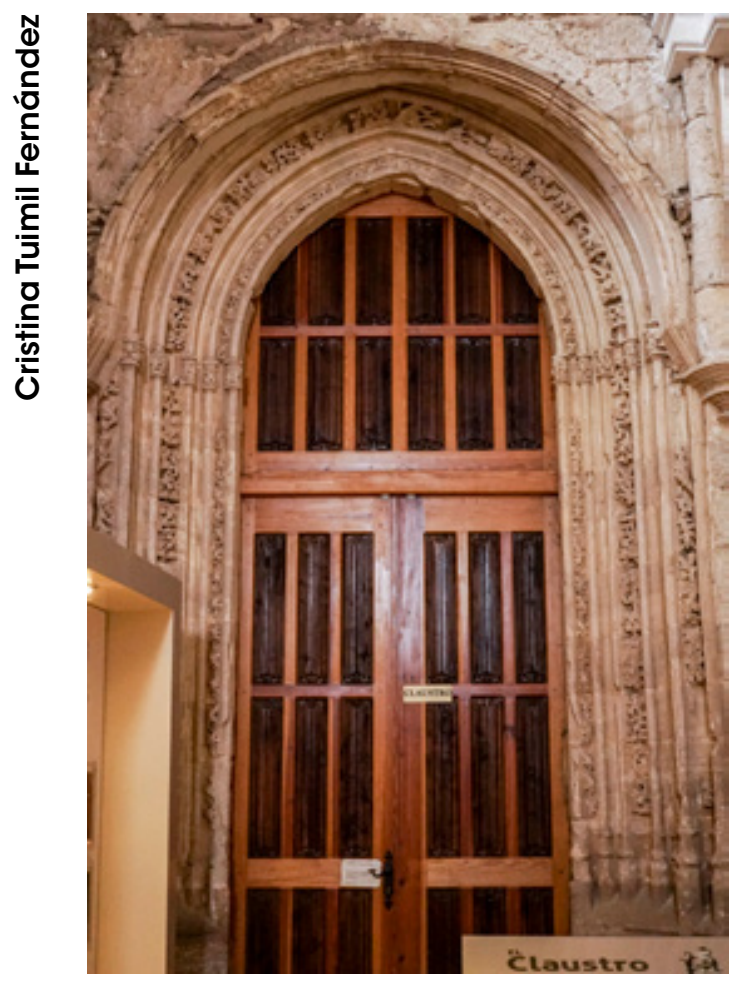

Fig. 7. Santa María de Sasamón. Puerta de acceso al claustro desde los pies de la nave septentrional. Siglos XV-XVI. Fotografía de Marina Garzón Fernández



Fig. 8. Santa María de Sasamón. Claustro. Vista interior de la panda oriental desde el ángulo sureste. Fotografía de la autora

(fig. 6), continuase en uso tras la construcción del claustro sirviendo de comunicación entre ambos espacios. Sin embargo, cuando se proyectaron las bóvedas a finales del siglo XV o principios del XVI fue necesario prescindir de ella para no romper el ritmo de los arranques, pues el soporte de uno de los tramos de la bóveda debía colocarse justo en ese punto. Se hizo entonces necesario crear un nuevo acceso: la puerta de estilo plateresco ubicada en el último tramo de la panda sur del claustro, es decir, muy próxima a la primera (fig. 7). Que esta segunda entrada fuese creada a raíz del levantamiento de las bóvedas no sólo lo demuestra el hecho de que la primera se encuentre tapiada por un arranque, sino la incoherencia que habría supuesto prescindir de un acceso todavía en uso para abrir otro a escasos metros.

Además, el estilo de esta nueva puerta parece confirmarlo. El arco ojival que la corona se intentó encuadrar con naturalidad en el de medio punto preexistente en el hueco en el que se integra ${ }^{25}$. Asimismo, su decoración vegetal se asemeja mucho a la que presenta una suerte de arcosolio -hoy vacío-, ubicado en el interior de una de las capillas en las que se divide la nave del siglo XVI, así como a la que se conserva en la portada que daba acceso a ella. Por tanto, no sería extraño pensar que esta puerta de acceso al claustro fuera abierta en el transcurso de esa misma campaña constructiva. Incluso pudo ser entonces cuando se proyectó el levantamiento de las nuevas bóvedas del claustro y se labraron esas ménsulas que tanta confusión han generado. De hecho, las esculturas que las decoran guardan franca semejanza formal con las que ocupan la portada meridional del siglo XVI, en las que puede apreciarse ese estilo propio de escultores alemanes (véase fig. 4).

Por otro lado, todavía hoy se perciben sobre el muro perimetral del claustro las cicatrices que han dejado los arcos formeros de las bóvedas. Estas, de forma evidente, no coinciden con el ritmo que marcan los arcosolios ni otros vanos como el de medio punto, situado en el ángulo noreste, que hoy alberga una escultura de la Virgen sedente con el Niño (fig. 8). Estas huellas indican que bóvedas y muros no fueron diseñados como un conjunto armónico y, por tanto, que sería extraño que formasen parte de la misma campaña constructiva.

Creo que todas estas particularidades demuestran que alzado y cubierta no forman parte de un proyecto uniforme diseñado como un todo y construido en un solo momento por un mismo taller. De ser así, estos desequilibrios no habrían tenido lugar. 
Pero no sólo el análisis arquitectónico evidencia la existencia de dos momentos constructivos separados ampliamente en el tiempo, sino que también lo hace la decoración heráldica labrada sobre distintos soportes. Que las ménsulas y los monumentos funerarios alojados en los arcosolios no pertenecen a la misma época lo demuestran las distintas formas que presentan los blasones esculpidos en cada uno de ellos. Por un lado, los de los sarcófagos siguen la forma propia de los siglos XIII y XIV, es decir, cuentan con un perímetro rectangular con los extremos de los lados inferiores redondeados, unos con el remate completamente semicircular y otros ligeramente apuntado (fig. 9). En cambio, el escudo con las armas papales que sostiene el ángel que habita una de las ménsulas, rematado en un arco conopial, sigue las formas propias de los siglos XV y $X V{ }^{26}$ (compárense figs. 4 y 9). Este mismo diseño muestran también los escudos que adornan el frente del sepulcro de Alvar Pérez, construido en 1444 y ubicado en la capilla de los Santos Juanes que, como ya se ha dicho, da acceso hoy en día al claustro27.

Así, suprimiendo las intervenciones modernas y obviando las modificaciones que trajo consigo la campaña constructiva de los siglos XV y XVI se presenta ante nosotros el primitivo claustro de Santa María de Sasamón, compuesto por el muro de cierre jalonado de arcosolios y el entramado de ventanas que se abren al patio.

\section{Un cementerio elocuente}

Para constatar que el diseño de muros y tracerías es muy anterior en el tiempo a lo que se viene creyendo bastaría con comparar el conjunto segisamonense con otros claustros que fueron construidos en los siglos XV y XVI, como los de las colegiatas de Santa María del Campo (Burgos) y Covarrubias (Burgos), el de la catedral de Segovia o el claustro bajo del monasterio de San Juan de los Reyes (Toledo). En ellos se advierte la diferencia radical que existe no sólo en la composición de las tracerías sino también en la imaginación arquitectónica del que las ideó. El arquitecto que trabajó en Sasamón siguió un sistema racional de series de subdivisiones subordinadas (véase fig. 13), mientras que para los más modernos la preocupación fundamental era la complejidad

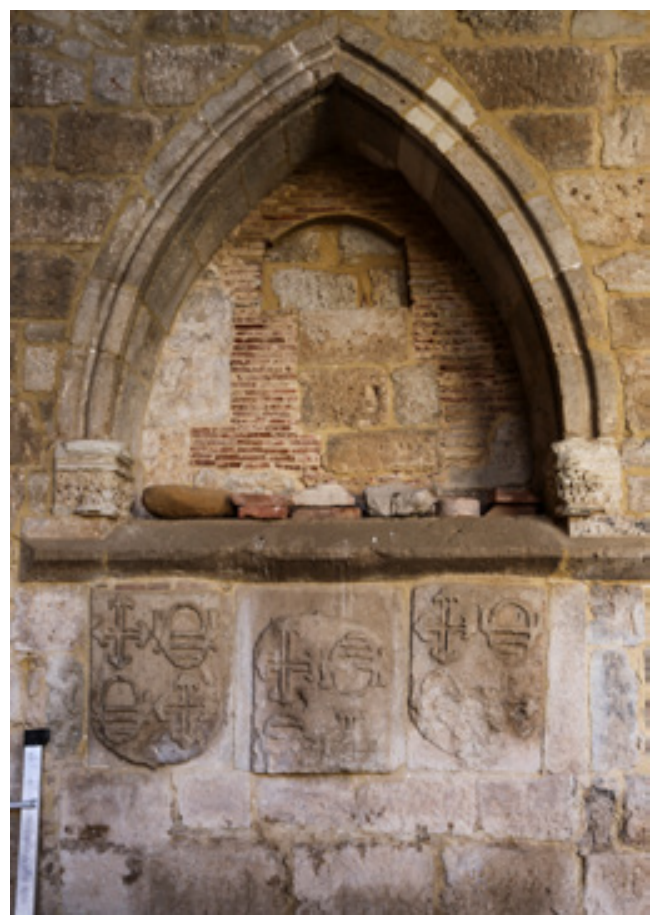

Fig. 9. Santa María de Sasamón. Claustro. Detalle de un arcosolio de la panda oeste. Fotografía de la autora

del diseño decorativo y la exuberancia de sus tracerías flamígeras. Incluso en el interior de sus pandas se observan las grandes diferencias que existen no sólo a nivel decorativo sino también en lo relativo a la articulación de muros y pilares.

Es con otro claustro, el claustro alto de la catedral de Burgos, con el que debe confrontarse el que nos ocupa, y esa comparación resultará mucho más productiva. Además de la similitud en el diseño de sus tracerías -que trataré con detenimiento en el siguiente apartado-, existe una clara identidad en la articulación mural que presentan ambos claustros. Como ya se ha dicho, en Sasamón los muros perimetrales se encuentran horadados por una sucesión de arcosolios. Este patrón, como advirtió hace años Christopher Welander ${ }^{28}$, es particularmente hispano y alcanzó una singular regularidad en el claustro alto de la catedral de Burgos, donde las paredes exteriores se configuran como una sucesión de profundos arcos ojivales enmarcados por pilares rectangulares que sobresalen marcadamente del muro, dando lugar a grandes arcadas que soportan las 


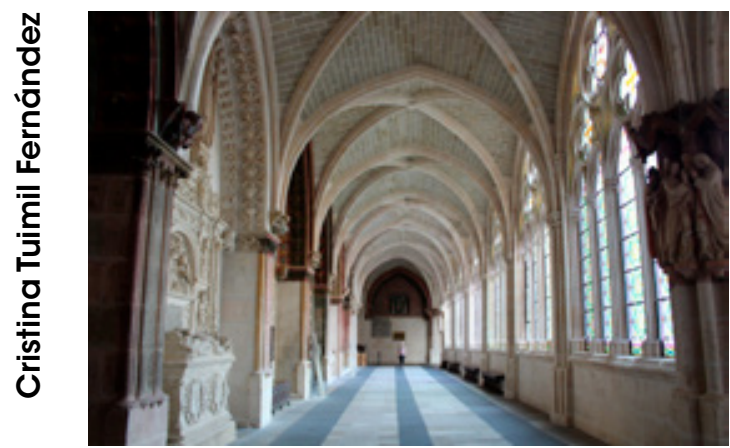

Fig. 10. Catedral de Burgos. Interior del claustro alto. Ca. 1265-1270. Fotografía de la autora

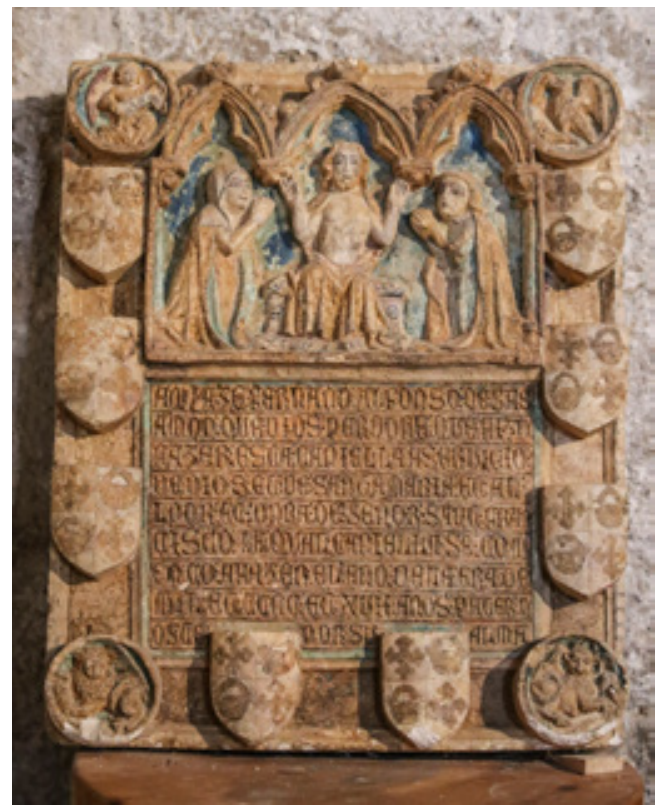

Fig. 11. Santa María de Sasamón. Lauda sepulcral reubicada hoy en la capilla de los Santos Juanes. Siglo XIV. Fotografía de la autora

bóvedas y que semejan un viaducto ${ }^{29}$ (fig. 10). En Sasamón el sistema mural es mucho más senciIlo, pues los arcosolios no ocupan la totalidad de los lienzos sino que han sido horadados directamente en un muro carente de articulación. Por ello, podría decirse que aquí se levanta una versión humilde del espacio claustral de la catedral vecina. Es un recinto de menores dimensiones condicionado seguramente por las menores posibilidades económicas de sus patronos, pero en su planteamiento general es evidente que pretendió imitar el diseño catedralicio (compárense figs. 2 y 10). En este sentido, el parentesco con Burgos no se encuentra solo a nivel formal sino, sobre todo, a nivel funcional.

La presencia de este claustro en Sasamón invita a preguntarse por el estatuto original de la iglesia. Los estudiosos le han conferido la dignidad de colegiata amparados en la existencia de este recinto y apelando a la memoria del esplendor del que había gozado el templo durante los años en que había sido sede episcopal, allá por el siglo $\mathrm{XI}^{30}$. Si bien es cierto que a partir del siglo $\mathrm{XV}$ ciertos datos permiten intuir la existencia de actividad colegial en Sasamón ${ }^{31}$, hasta ahora nada sugería la presencia de una comunidad -regular o secular-durante los siglos XIII y XIV. Esta, además de la filiación estilística alemana de la decoración de las ménsulas, era una de las razones de peso para adscribir el claustro al siglo XV. Sin embargo, en los testamentos -todavía inéditos- de Martín Ibáñez de Sasamón (†1333) y Juan Rodríguez de Sasamón (†1354), dos miembros destacados del cabildo burgalés en la primera mitad del siglo XIV, se hace referencia en varias ocasiones "a los clérigos de Sasamón" y, lo que es más, "a los clérigos de la cofradía de Sasamón" ${ }^{32}$. Este dato, aunque no es suficiente para atestiguar la existencia de un cabildo colegial33, sí lo es para suponer una suerte de actividad comunitaria y regulada en este templo, que no parece haber sido una simple iglesia parroquial.

Debido al clima de desconocimiento que todavía impera sobre esta cuestión, sería arriesgado afirmar que este espacio hubiese sido creado como marco para actividades derivadas de la cofradía. Sin embargo, atendiendo a la configuración de sus muros, no resulta tan osado proponer que el claustro de Sasamón haya servido para otros fines: las tumbas que lo recorren sugieren que estuvo destinado a servir como cementerio privilegiado. Ya Eduardo Carrero en su artículo sobre los claustros funerarios en la Edad Media había incluido a Sasamón entre una serie de ejemplares que respondían a fines deliberadamente cementeriales ${ }^{34}$. Esta nueva tipología claustral, vinculada a la necesidad de crear un espacio de enterramiento privilegiado próximo a la iglesia, habría nacido en la catedral de Salamanca y alcanzado una gran difusión en territorio peninsular desde finales del siglo XIII y especial- 
mente durante el XIV. Ejemplos destacados son los de las catedrales de León, Oviedo y Ciudad Rodrigo o los de iglesias colegiales o parroquiales como San Esteban de Burgos. Es, a esta familia, a la que pertenece Santa María de Sasamón.

El claustro segisamonense cuenta con un total de diecisiete arcosolios repartidos fundamentalmente en sus pandas este (6) y oeste (8), y en menor medida en la norte (2) (véase fig. 1). Todos ellos rematan en su parte externa en un simple bocel y alojan sarcófagos (véase fig. 9). Por desgracia, como Cristóbal Villanueva señala en su informe ${ }^{35}$-y como se puede apreciar a simple vista-, todos han sido reutilizados en diversas ocasiones a lo largo de los siglos y sobre todo en época moderna, lo que ha provocado importantes modificaciones y pérdidas con respecto a su estructura y decoración original.

Atendiendo a la forma del arco y a los elementos que lo soportan, parece probable que los primeros en levantarse hayan sido los de la crujía este y, por tanto, que se hubiese empezado por ahí la construcción del claustro. Estos arcosolios son más anchos y menos apuntados que los de las pandas restantes, y las jambas y capiteles que les sirven de arranque -y entre los que se alojan los sarcófagos- son muy similares a los que soportan las arquerías del cuerpo de ventanas. Los de las pandas norte y oeste, por su parte, presentan arcos más estrechos y apuntados y sus capiteles están formados por un simple bocel ${ }^{36}$. La sencillez de estas estructuras dificulta la tarea de su datación, pero los escudos con decoración heráldica dispuestos en el frente de tres de los sarcófagos de esta panda oeste ayudan a afinar las fechas. La forma de estos blasones y el hecho de que ocupen la totalidad del frente de la urna permiten encuadrarlos en la primera mitad del siglo $\mathrm{XIV}^{37}$. Es posible señalar paralelos con una cronología similar como son los sepulcros de Alfonso de Valencia (post. 1316) o Diego Yáñez (post. 1309), en el claustro de la catedral de León ${ }^{38}$, o el sepulcro de Lopo Fernández Pacheco (ca. 1349), en la catedral de Lisboa.

Todos los escudos presentes en el claustro segisamonense presentan, además, el mismo blasón con un cuartelado en cruz: primero y cuarto, una cruz flordelisada; segundo y tercero, una caldera (véase fig. 9). Estas armas parecen pertenecer a la olvidada familia de los Sasamón como revela una lauda sepulcral recolocada hoy en la capilla de los Santos Juanes, en la que puede leerse:

AQ(U)I YAZE HERNAND(O) ALFONSO DE SASI AMON QUE DIOS PERDONE QUE HIZOI HAZER ESTA CAPIELLA A SEVICIOI DE DIOS ET DE SANTA MARIA ET AL/ LOOR ET ONRA DE SENOR SANT FRAN/CISCO LA QUAL CAPIELLA SE COMIENCO A HACER EL ANO DE LA ERA DEI MIL ET CCCC ET XVII ANOS PATER NIOSTER POR SU ALMA ${ }^{39}$ (fig. 11).

Sus cuatro ángulos se decoran con las imágenes de los cuatro evangelistas y entre ellos se labraron escudos blasonados y pintados, todos ellos cuartelados: primero y cuarto de oro (¿o quizá gules?), una cruz flordelisada de sable; segundo y tercero de plata, una caldera de sable (¿O azur?). Las medidas de esta placa rectangular coinciden quizá no por caso con el hueco que presenta en su fondo uno de los arcosolios del claustro que cuenta, además, con escudos cuartelados en el sarcófago que alberga. Este espacio parecería apropiado para su ubicación original y permitiría confirmar la existencia del claustro hacia la era de 1417 o, lo que es lo mismo, en el año $1379^{40}$.

Por desgracia, el paso del tiempo y las malas condiciones en las que ha vivido el claustro han provocado la pérdida de la policromía de esos escudos sepulcrales, lo que impide conocer las similitudes o diferencias a este respecto con el blasón perteneciente a Hernando Alfonso de Sasamón. A pesar de ello, parece más que probable que todas estas armas pertenezcan a un mismo linaje que además, como bien revela su alcuña, debía guardar una íntima relación con la villa.

Otro arcosolio de la panda occidental alberga una pequeña placa funeraria de $40 \times 30 \mathrm{~cm}$ con inscripción en letra gótica que reza:

AQ' IAZE P(er)O G'ome)S CRIADO DE ROY P(ere) SI E FINO XXI DIAS DE DIZIEMBRE ERAI DE MIL E CCCLXXI ANNO E SU MUIGIER MARIA G(ome)S Q(Ue) DIOS LOS/ P(er)DONE AMEN PATER NOSTER/ POR SUS ALMAS ${ }^{41}$ (fig. 12)

Bajo el texto se extiende una franja en relieve decorada con una figura sedente de la Virgen, flanqueada a izquierda y derecha por sendos escudos. El de su izquierda está prácticamente destruido pero el de su derecha muestra otro 


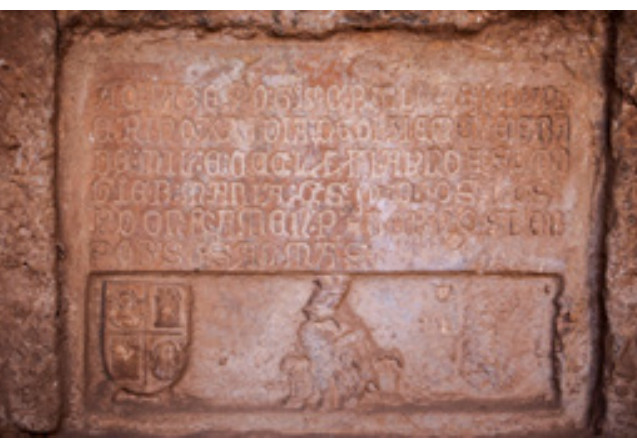

Fig. 12. Santa María de Sasamón. Lauda sepulcral recolocada en la parte inferior de un arcosolio de la panda oeste. Siglo XIV. Fotografía de la autora

cuartelado en cruz: primero y cuarto, una caldera; segundo y tercero, un castillo. Aunque esta no parece ser la ubicación original de la placa, no cabe duda de que la inscripción formaba parte de un sepulcro. De haber pertenecido a uno de los arcosolios del claustro podría confirmarse su existencia al menos "en el año de la era" de 1371, es decir, en el año 1333.

Por otro lado, es probable que el "ROY P(ere)S" de la inscripción no sea otro que Roy Pérez de Sasamón, uno de los miembros más destacados de esta familia desde finales del siglo XIII -ya en 1285 y 1291 aparece como testigo en dos documentos expedidos por Sancho IV ${ }^{42}$ - y especialmente durante las primeras décadas del siglo XIV. De él se dice que albergó en su casa de Palencia a Fernando IV cuando este cayó gravemente enfermo en $1308^{43}$, y que llego a ser, entre otras cosas, notario de Fernando IV44, "ome" de María de Molina -como ella misma lo denomina en un documento de $1316^{45}$ - y despensero mayor del rey Alfonso XI en $1327^{46}$. Juan Rodríguez -cuyo testamento ha sido citado- y Rodrigo Rodríguez de Sasamón parecen haber sido hijos de Roy Pérez. Juan fue canónigo de Burgos y Valladolid hasta su muerte en $1354^{47}$, habiendo seguido los pasos de su padre como despensero mayor de Alfonso $\mathrm{XI}$ en $1330^{48}$. Recibe, además, la denominación de "clérigo regio" 49 y él se alude en una bula del papa Benedicto XII como "familiar" del Rey Alfonso $X^{50}$-familiar, por supuesto, en el sentido de familia cortesana y no de sangre. Rodrigo, por su parte, fue canónigo de Covarrubias, canónigo de Palencia ${ }^{51}$ y abad de Valladolid entre al menos 1324 y $1358^{52}$. Martín Ibáñez que, como indicaba

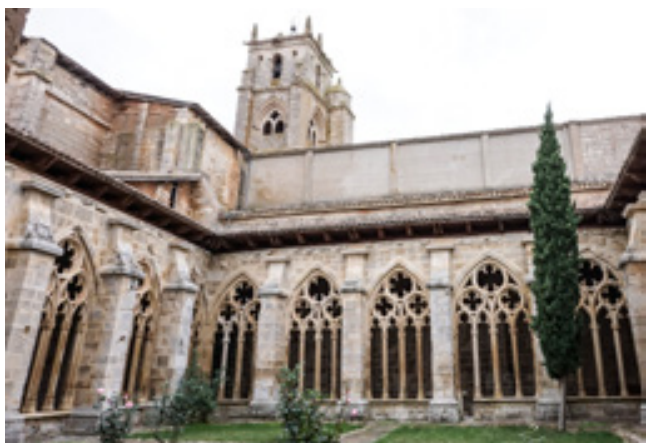

Fig. 13. Santa María de Sasamón. Claustro. Vista general desde el patio. Fotografía de la autora

su testamento, fue prior de la catedral de Burgos hasta su fallecimiento en 1333, también formaba parte de este linaje ${ }^{53}$.

Una familia, esta de los Sasamón, que sin duda desempeñó un papel destacado en la vida política y religiosa de - al menos- el final del siglo XIII y la primera mitad del XIV en Castilla. Aunque los datos que he recabado hasta el momento no permiten elaborar un árbol genealógico fiable, su memoria merece ser recuperada pues podría haber sido ese nexo entre Sasamón y el exterior que resultaría tan importante para comprender el trasfondo histórico que se encuentra detrás de la fábrica segisamonense. La repetición de las que parecen ser sus armas en laudas y sarcófagos blasonados evidencian que la familia de los Sasamón debió jugar un papel activo en la fábrica de la villa que les ha dado nombre, un hecho que vendría a confirmar una vez más la temprana datación del claustro.

\section{Un diseño radiante}

Pero además de la similitud en la articulación del perímetro mural, la relación entre el claustro de Sasamón (fig. 13) y el claustro alto de la catedral Burgos (fig. 14) viene sostenida por la identidad de diseño de sus ventanales, organizados según un esquema de subordinación propio del gótico radiante francés (compárense figs. 13 y 14). En ambos casos, en cada tramo y sobre una repisa baja, se abren arcos de tracerías subdivididos en dos grandes lancetas coronadas por un rosetón hexalobulado. Cada lanceta acoge a su vez el mismo esquema a menor escala, de modo 
que cada una de ellas alberga otras dos lancetas coronadas esta vez por pequeños óculos cuadrilobulados. La elegancia de las trazas se extiende, además, a la ligereza y delgadez de los maineles (véanse figs. 2 y 10). En los dos claustros los pilares de los muros de las ventanas están dispuestos a modo de haces de columnillas que se destacan plásticamente ${ }^{54}$. Estos arrancan de un pedestal en el que se observa la única diferencia notable entre los dos conjuntos, pues un desarrollo más complejo en el caso segisamonense permite que alcancen una altura superior con respecto al fuste y obtengan así mayor relieve y plasticidad. En el claustro catedralicio, el pedestal inferior está compuesto de tres resaltos rectangulares escalonados. El ejemplo de Sasamón, pese a seguir la misma configuración, varía en su diseño: las molduras planas y rectangulares se prolongan y se unen a las columnas mediante un juego de molduras cóncavas y convexas que evoca una mayor complejidad55. En ambos casos, sobre estas basas y a un nivel un poco inferior al zócalo sobre el que arrancan las ventanas, nacen cinco columnillas ligadas entre sí por una escocia ininterrumpida ${ }^{56}$. Las tres columnillas centrales están rematadas a la misma altura por capiteles que reciben un arco perpiaño y dos nervios en el caso de Burgos $^{57}$, y aunque resulta difícil saberlo para el caso de Sasamón porque las bóvedas desaparecieron, todo parece indicar que se organizaban del mismo modo. Las dos columnillas restantes se prolongan hacia arriba, sustentando los arcos formeros adosados. Los capiteles se sitúan a una altura ligeramente mayor en el caso catedralicio. Al exterior, en el patio, las similitudes siguen siendo más que evidentes. Incluso los ángulos, en donde convergen dos pandas, se configuran de un modo casi idéntico compartiendo la columnilla -y su respectivo capitel- en la que desembocan ambas arcadas.

Las fechas documentadas para la construcción del claustro alto de la catedral burgalesa, que estaría rematado hacia $1270^{58}$, y el estrecho parentesco que el diseño del de Sasamón guarda con él invitan a proponer una fecha ligeramente posterior para su levantamiento. Por otro lado, es lógico pensar que el claustro de Sasamón sea una copia directa e intencionada del claustro alto de Burgos si tenemos en cuenta que esta no es la única "cita" de la catedral vecina que se en- cuentra en este edificio. Como es bien sabido, en la portada meridional del siglo XIV del conjunto segisamonense se lleva a cabo una versión de la portada del Sarmental de la catedral de Burgos.

Curiosamente, entre la escasa documentación conservada se encuentran una serie de Privilegios Reales concedidos a Sasamón ${ }^{59}$, entre los que destacan especialmente los otorgados por Sancho IV y su hijo Fernando IV. Sancho IV, en 1284, confirma la exención de portazgo concedida originalmente por su bisabuelo y confirmada por su abuelo y su padre, que liberaba de todo pecho real a los vecinos de la villa. En 1288, ya de forma más detallada, dispone que a los de Sasamón:

Se les quite de toda puesta e de toda facendera e de portazgo e de todo pecho que a rrey pertenesce en tal manera que según ellos ovieren las riquezas que lo metan en fauor de la yglesia de santa maria de $y$ dese lugarbo.

En otro privilegio concedido en 1294, tiene "por bien, e porque nos [Sancho IV] vemos que Dios muestra muchos miraglos e tienen muy buena obra començada porque se acabe mas ayna", permitir que recauden dinero por todo su reino ${ }^{61}$. Fernando IV, además de ratificar en 1299 y 1302 los privilegios expedidos anteriormente por su padre, ordena explícitamente que "todo aquel pecho que ouieren a dar a mi que lo metan en la labor de la iglesia de santa maria de sasamon cada año" y autoriza asimismo al pueblo de Sasamón a la recogida de dinero por todo el reino para la obra de la "iglesia sin que pudiera ser intervenida ni embargada de ninguna manera saluo fecho de la cruzada sy y fuere ese día presente" ${ }^{62}$. Además, en otro privilegio de 1304, incide en los derechos y libertades de los habitantes de Sasamón:

Nin les consintades otrosy que les pasen contra los previllegios (...) e sy alguno y oire que les querrán pasar contra ellos prendadle por la pena que en ellos se contiene e vendedla luego e guardad los marauedis que de ella fizieredes e enviádmelo decir luego ${ }^{63}$.

Es probable, por tanto, que el levantamiento del claustro y la gran ampliación de la cabecera se promoviesen a lo largo de este periodo de veinte años en torno al cambio de siglo, en el que la situación económica de la villa debió de ser ex- 


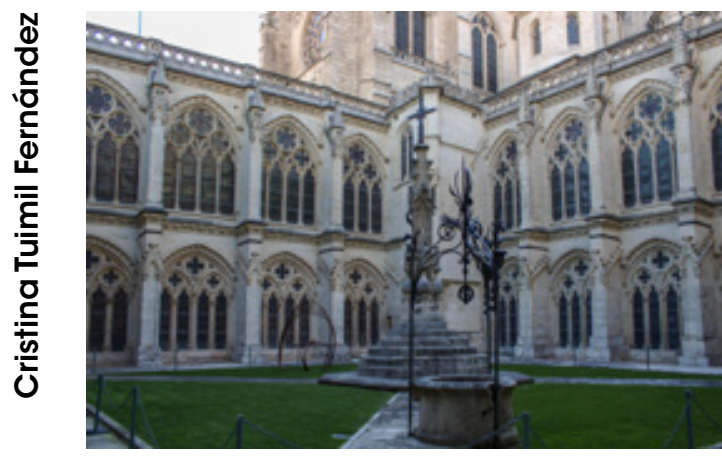

Fig. 14. Catedral de Burgos. Claustro. Vista general desde el patio. Ca. 1265-1270. Fotografía de la autora

celente gracias a las consecuencias derivadas de los privilegios otorgados por estos dos monarcas.

Sin embargo, la construcción debió prologarse durante buena parte del siglo XIV pues en las dos confirmaciones siguientes, la de Alfonso XI en 1322 y la de Enrique II en $1367^{64}$, los reyes manifiestan que conceden estos privilegios para que "los de este lugar puedan mejor e mas cumplidamente labrar o acabar la obra de santa maria que tienen encomenzada a seruicio de Dios e de santa maria" 65 . A partir de esta última, en cambio, las confirmaciones se vuelven más escuetas y dejan de hacer referencia al estado de construcción de la obra. ¿Quizá porque estaba ya acabada? De aquí en adelante, estos privilegios seguirán siendo simplemente confirmados hasta el reinado de Fernando VII en el siglo XIX.

Pero ¿a qué se debe este favor con los habitantes de la villa y qué interés tiene la Corona en la construcción de esta iglesia? ${ }^{66}$ Lejos de poder ofrecer una respuesta certera a esta incógnita, ¿es posible que este incremento de concesiones regias durante los reinados de Sancho IV y Fernando IV se deba a la influencia de la "familia de los Sasamón", teniendo en cuenta la estrecha relación que parece haber mantenido este linaje con la monarquía castellana?

Retomando el análisis formal, resulta interesante destacar que el claustro de Sasamón no sólo guarda parecido con el de la catedral de Burgos sino también con el de la catedral de Pamplona, en concreto con los tramos correspondientes a su primera etapa constructiva ${ }^{67}$ (fig. 15). Esta primera fase, que Clara Fernández-Ladreda fecha

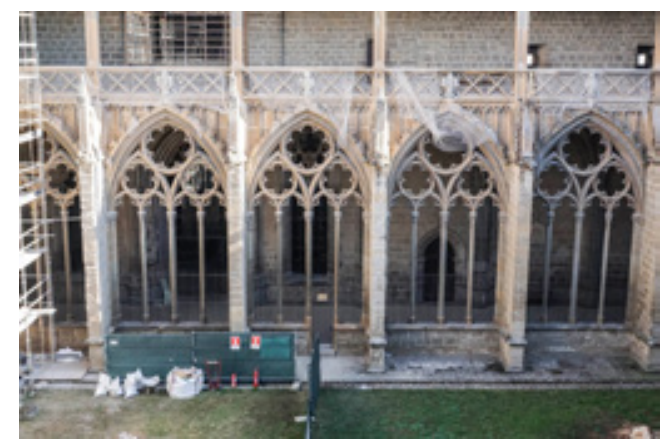

Fig. 15. Catedral de Pamplona. Claustro. Vista de la panda este desde el patio. Ca. 1280-1318. Fotografía de Marina Garzón Fernández

entre los años 1280 y 1318, abarcaría fundamentalmente la panda este del claustro -excepto el tramo más meridional, y la bóveda y tracería del ventanal del inmediatamente anterior-, y la mitad oriental de la norte, así como la cripta de la sala capitular y los muros del piso superior ${ }^{68}$. Este primer momento se caracteriza por la presencia de un tipo de tracería -la más sencilla de las que conforman el claustro- que sigue el mismo esquema compositivo que las de Burgos y Sasamón, con la diferencia de que presenta un juego de óculos de seis y ocho lóbulos en lugar de cuatro y seis ${ }^{69}$.

La composición de estos ventanales, como bien apunta Clara Fernández-Ladreda, estaba muy difundida por esta época, contando con múltiples variantes especialmente en la zona de París, de modo que hacia 1300 resultaba un tanto anticuada $^{70}$. Un diseño semejante se repite en el primero de los tramos del claustro del monasterio de Santa María de la Oliva a inicios del siglo XIV¹. Un claustro que, como el de Pamplona, vio el sucederse de distintos diseños de tracerías a medida que avanzaba su construcción hasta el siglo XV, aumentando su complejidad y preciosismo con el paso de los años.

Así, los claustros de estos cuatro templos -Burgos, Sasamón, Pamplona y La Oliva- no dejan lugar a dudas de la buena acogida que el gótico radiante tuvo en Castilla y Navarra durante los siglos XIII y XIV.

En conclusión, creo haber aportado argumentos suficientes para demostrar que la construcción del claustro de Sasamón se llevó a cabo en dos etapas bien diferenciadas. La primera, que 
podría fecharse en torno a finales del siglo XIII y primera mitad del XIV, se ajusta a una estética propia del más puro gótico radiante siguiendo los ejemplos de las catedrales de Burgos y Pamplona. Si tenemos en cuenta, además, que los ventanales de Sasamón son todavía más sencillos que los de Pamplona al presentar un juego de tracerías de cuatro y seis lóbulos en lugar de seis y ocho, podríamos aventurarnos a decir que Sasamón se proyecta antes o paralelamente al inicio de esta primera etapa pamplonesa (1280), coincidiendo con la cronología post quem que proporciona el claustro de Burgos (1270) y con el privilegio concedido por Sancho IV en 1294 en el que el rey dejaba constancia de que tenían "muy buena obra començada". Es posible que la construcción se iniciara por la panda este que, como se ha dicho, alberga los arcosolios aparentemente más antiguos, y se rematase por la oeste, donde se encuentran los nichos cuya heráldica parece corresponder a esa familia que detenta cierto poder en el siglo XIV. La segunda campaña, Ilevada a cabo entre finales del siglo $X V$ y principios del $\mathrm{XVI}$ por artistas formados en una corriente de marcado gusto alemán, habría modificado el conjunto levantando las bóvedas que, posiblemente, no se habían lanzado en la primera fase. Es más que probable que la consecución de la dignidad de colegiata, que parece haber tenido lugar en este momento, tuviese como consecuencia importantes intervenciones arquitectónicas -no sólo en el claustro, pues recuérdese que es en este momento cuando se construye la sacristía y la sala capitular adosadas a la cabecera- con el fin de adaptarse a las nuevas funciones que este cargo acarreaba y revestirse del prestigio que conferían las nuevas modas. 


\section{NOTAS}

* Este trabajo se enmarca dentro de la realización de la tesis doctoral Santa María de Sasamón: fragmentos para la historia de una colegiata olvidada, dirigida por Rocío Sánchez Ameijeiras.

1 Únicamente la portada sur ha sido revisada en las últimas décadas por autoras como Julia Ara Gil, "Escultura", en Historia del arte de Castilla y León, t. III: Arte Gótico (Valladolid: Junta de Castilla y León, Consejería de Cultura y Turismo, 1995), 240; o Rocío Sánchez Ameijeiras "La portada del Sarmental de la Catedral de Burgos. Fuentes y Fortuna", Materia 1, L'estil (2001): 195198.

2 Incluido en el Libro de Fábrica y cuentas de la iglesia de Sasamón: 17891850. Archivo Diocesano de Burgos, armario 43, sig. 8, s.p. En él se declara que: (...) las ocurrencias que hubo durante la dominación francesa, quando se llevaron todos los ganados y los susos dichos bueyes las partidas de guerrilla, habiendo también desaparecido el Libro de Fundación, visitas y todos los papeles relativos á ella como los demás de la iglesia en el incendio ocurrido posteriormente que redujo a cenizas toda la población. También se deja constancia de que el incendio tuvo lugar en 1812.

3 Ya el propio Vicente Lampérez y Romea ("La iglesia de Santa María en Sasamón (Burgos)", La ilustración española y americana, año XLVIII, $n^{\circ} \mathrm{XLI}$, 1904: 270) intuía: Todo es misterioso en Sasamón, y acaso lo será eternamente, pues el archivo desapareció entre las llamas en los días de nuestra guerra de la Independencia.

${ }^{4}$ Alejandro Orive Salazar, Sasamón: ciudad milenaria y artística (Burgos: Diputación Provincial, 1969), 96. El cuerpo de naves ha sido reconstruido tras los graves daños que había sufrido en el incendio, en el que se vinieron abajo las bóvedas y se debilitaron enormemente los muros. Se llevaron a cabo pequeñas obras a lo largo del siglo $X X$ y fue entre 1962 y 1964 cuando se levantaron las bóvedas y pilares actuales. La intervención se explica con detalle en una memoria de obra conservada en el Archivo General de la Administración, elaborada por el arquitecto Marcos Rico
Santamaría a fecha de abril de 1961 (Archivo General de la Administración, Carpeta 52/4287).

5 Andrés Oroño Díaz y Miguel A. López Miguel, Santa María la Real de Sasamón (Burgos): estudio técnico (Burgos: Junta de Castilla y León, Dirección general de patrimonio y promoción cultural, 1992), 34-35.

6 S. De la C., "Segisamún ayer: Sasamón hoy", Revista Contemporánea, año X, tomo XLIX (enero-febrero 1884): 388. He intentado rastrear la identidad de este autor pero no he tenido éxito.

7 Eloy García de Quevedo y Concellón, "Excursiones por la provincia de Burgos: conferencia dada en el Ateneo de Madrid el 17 de marzo de 1899", Sociedad Española de Excursiones, año VII, n 82 (diciembre 1899): 205.

8 Lampérez y Romea, "La iglesia de Santa María en Sasamón", 270. Es interesante reseñar que en este momento Vicente Lampérez estaba trabajando en la restauración de la catedral de Burgos.

9 Luciano Huidobro y Serna, "Sasamón: villa de arte", Boletín de la Sociedad Castellana de Excursiones, t. V (1912): 118.

10 Teófilo López Mata, "Santa María de Sasamón", Boletín de la Institución Fernán González, X (1952-1953): 553.

11 Matías Martínez Burgos, "En torno a la catedral de Burgos", Boletín de la Institución Fernán González, 131 (1955): 55.

12 Orive Salazar, Sasamón, 41: Perla de singular valor, dentro de la maravillosa joya, de que nos venimo ocupando, obra maestra y mimada de Juan de Colonia, es juntamente con el de Fredesval, del mismo insigne maestro, la más primorosa pieza del más depurado estilo gótico.

13 Salvador Andrés Ordax, Iconografía cristológica a fines de la Edad Media: el crucero de Sasamón (Universidad de Extremadura: Servicio de Publicaciones, 1986), 21.

14 Orive Salazar, Sasamón, 44: Con el importe de una bella, aunque deteriorada alfombra persa de la Parroquia, se construyó un fuerte zuncho de hormigón para sujetar y fortificar la colum- nata y la arquería, en parte bastante desequilibrada y se le cubrió con buen tejado y airoso tejaroz que si bien es cierto le ha robado un poco de romanticismo a sus espléndidas ruinas, ha tenido la fortuna de evitar su demolición total.

15 Andrés Oroño Díaz y Miguel A. López Miguel, Memoria final de la restauración del claustro de la colegiata de Santa María de Sasamón (Burgos) (Burgos: Junta de Castilla y León, Dirección general de patrimonio y promoción cultura, 1998), 3-9. Se explica así la presencia de esos desconcertantes capiteles pinjantes en el nuevo paso al jardín. Estas son solo una parte de las intervenciones llevadas a cabo en esta campaña de restauración, entre las que he destacado las que considero más importantes o relevantes para este estudio. Se especifican todas con detalle en la memoria citada.

${ }^{16}$ Eduardo Cristóbal Villanueva, Informe técnico sobre la intervención arqueológica de urgencia realizada en el claustro de Santa María la Real de Sasamón (Burgos) (Burgos: Junta de Castilla y León, dirección general de patrimonio y promoción cultura, 1997), 204.

17 Isaac Rilova Pérez y Jesús Simón Rey, Sasamón: Historia y guía artística (Burgos: Editorial Dossoles, 2005), 364.

18 Oroño Díaz y López Miguel, Santa María la Real de Sasamón, 21. No justifican, sin embargo, por qué en esta ocasión adscriben el claustro al siglo XIV.

19 Ibídem, 16.

20 Eduardo Carrero Santamaría, "Compostela, pauta y evocación en el Pórtico del Paraíso de la catedral de Ourense", en Modelo, copia y evocación en el románico hispano, coord. Pedro Huerta Huerta (Palencia: Fundación Santa María la Real del Patrimonio histórico, 2016), 97-100. Se propone aquí una casuística similar para el Pórtico del paraíso de la catedral de Ourense.

${ }^{21}$ De la habilidad de los talleres alemanes en estas cuestiones dan cuenta tanto las espectaculares bóvedas de la sacristía y el cuerpo de capillas levantadas en el siglo XVI, como los arreglos que en estas mismas fechas realizaron en las bóvedas de los tramos más orien- 
tales del crucero y en las de algunas de las capillas de la cabecera.

22 Son varios los ejemplos de claustros cuyas bóvedas fueron realizadas o reemplazadas en el siglo XVI. Parece una práctica común en este siglo. El caso más paradigmático es quizá el del claustro de la catedral de León, cuyas bóvedas son del XVI a pesar de que el recinto fue construido entre finales del siglo XIII y principios del XIV. Al igual que en Sasamón, todavía no ha sido posible saber con qué tipo de cubierta contaba originalmente. Véase Henrik Karge, "La arquitectura de la catedral de León en el contexto del gótico europeo", en Actas de Congreso internacional "La Cateral de León en la Edad Media", eds. Gerardo Boto Varela, Victoria Herráez Ortega y Joaquín Yarza Luaces (León: Universidad de León, 2004), 132133. Por el contrario, en otros claustros como el de la catedral de Salamanca se ha conservado la cubierta de madera desde sus orígenes.

${ }^{23}$ Oroño Díaz y López Miguel, Santa María la Real de Sasamón, 37.

${ }^{24}$ Aunque no puedo afirmar con total seguridad que ese arco tapiado fuese originalmente un arcosolio similar a los que componen el claustro, todo parece indicar que así pudo haber sido pues su forma y su altura concuerdan con las del arcosolio situado a su izquierda. Sin embargo, si se reconstruyese el intradós en su anchura original, este llegaría a superponerse al arcosolio que se abre a su derecha. Lo que pudo haber ocurrido con estos dos nichos es una problemática pendiente de aclaración y cuyo estudio excedería los límites de este trabajo. Por el momento, resulta imposible sobrepasar el terreno de la hipótesis.

${ }^{25}$ Oroño Díaz y López Miguel, Santa María la Real de Sasamón, 55. Para estos arquitectos la puerta pertenece a la primera mitad del siglo XVI, en la transición del último gótico al renacimiento. Dejan constancia, además, de que esta portada rompe los esquemas del conjunto, ya que está rodeada de construcciones tardorrománicas, percibiéndose incluso que el primer arco, aún con herencia románica, no es de la portada sino de un tramo de la Iglesia, posible capilla, que parece estuvo cu- bierta a un nivel más bajo que la bóveda actual. Sin embargo, no citan la fuente de la que extraen esta información ni aportan ninguna información sobre esa supuesta capilla. A mi juicio, también podría tratarse de un hueco utilizado a modo de hornacina como los que se abren a lo largo de ese muro.

26 Ottfried Neubecker, Le grand livre de I'héraldique (París: Elsevier Séquoia, 1977), 77.

${ }^{27}$ Esta capilla es objeto de otra de las incoherencias constructivas que provocaron la errónea datación del claustro. Cristóbal Villanueva (Informe técnico, 204) la utiliza como argumento para reforzar la teoría establecida: el claustro debía ser indiscutiblemente posterior a 1444 ya que, según él, está apoyado en el lado oriental de la capilla funeraria de Alvar Pérez, criado de Pedro de Cartagena, que está datada, según consta en una lápida, en el año 1444. Lo que este autor pretende demostrar es que, si el claustro hubiese existido antes de la creación de esta capilla (supuestamente levantada en 1444, aunque realmente no se sabe con certeza si existió otra construcción previa ni si realmente esa lauda hace alusión a todo el espacio o únicamente al monumento funerario en el que se encuentra), este habría ocupado ese espacio, es decir, se hubiese prolongado un tramo más hacia el este hasta colindar con la nave del crucero. Sin embargo, según la teoría que en el presente estudio se está defendiendo, la construcción del perímetro del claustro se habría iniciado con anterioridad a la ampliación del crucero y la cabecera, y por lo tanto se habría proyectado hasta el límite que en aquel momento establecía el cuerpo de naves -y quizá la primitiva cabecera, hoy perdida-

${ }^{28}$ Sobre la concepción estructural del claustro de la catedral de Burgos como cementerio véase Christopher Welander, "The Architecture of the Cloister of Burgos Cathedral", en Medieval Architecture and Its Intellectual Context. Studies in Honour of Peter Kidson, eds. Eric Fernie y Paul Crossley (Londres: The Hambledon Press, 1990), 159-169.

29 Así los denomina Karge en su descripción del claustro burgalés. Henrik Karge, La catedral de Burgos y la ar- quitectura gótica del siglo XIII en Francia y España (Valladolid: Junta de Castilla y León, 1995), 257.

${ }^{30}$ Algunos autores, entre los que destaca Enrique Flórez, defienden la existencia de una iglesia previa a la hoy existente que llegó a ser sede episcopal durante un breve periodo del siglo XI. Varios documentos dan noticia de un obispo llamado Munio en Sasamón durante la segunda mitad del siglo XI $y$, cinco parecen acreditar su existencia entre al menos 1068 y 1076 -aunque el grado de veracidad de alguno de ellos puede llegar a ser cuestionable-. De ser cierta la existencia de la sede episcopal, ésta habría nacido durante la conquista musulmana y la consecuente necesidad de replegarse hacia el norte. Este hecho explicaría su naturaleza efímera, e impensable en circunstancias normales.

31 Hacia finales del siglo XV hay constancia de un abad llamado Diego Pardo. Véase Eduardo Pardo de Guevara y Valdés, De linajes, parentelas y grupos de poder. Aportaciones a la historia social de la nobleza bajomedieval gallega (Madrid: Fundación cultural de la nobleza española, 2012), 218. Por otro lado, el párroco Alejandro Orive constata la existencia de hasta 23 miembros del cabildo en 1751. Orive Salazar, Sasamón, 67.

32 La transcripción de estos dos testamentos, todavía inéditos, ha sido realizada por Susana Guijarro González. Son los testamentos de Martín Ibáñez, prior de catedral de Burgos hasta su fallecimiento en 1333 (testamento con fecha 30/07/1333. ACB, vol. 48, fol. 319) y Juan Rodríguez, canónigo de la catedral de Burgos hasta su fallecimiento en 1354 (testamento con fecha 08/03/1354. ACB, vol. 18, fol. 507), ambos conservados en el Archivo $\mathrm{Ca}$ tedralicio de Burgos. Su estudio forma parte del libro de Susana Guijarro, El bien façer, el buen morir y la remembranza en la sociedad medieval burgalesa (siglos XIII-XV) (Santander: Editorial de la Universidad de Cantabria, Santander, 2016) así como de un Proyecto en curso titulado Cultura, poder y redes sociales en la Castilla medieval: el clero de la diócesis de Burgos y Sigüenza en la Baja Edad Media (MINECO, Plan Nacional I+D+i, HAR2016-79265-P). Agradezco enormemente a Susana su ayuda 
y su amabilidad al haberme proporcionado el acceso a estos documentos.

33 Es necesario dar tanta importancia a las ausencias como a las presencias, y resulta demasiado extraño que todos los miembros de ese "linaje Sasamón" que llegan a ser canónigos de Burgos, Palencia, Covarrubias o VaIladolid, no ostentasen también el cargo en Sasamón de haber existido la posibilidad. En la documentación analizada hasta el momento, a ninguno de ellos se le atribuye esta dignidad, ni tampoco a Santa María de Sasamón, que es citada siempre como iglesia. Esta es una vía de investigación muy compleja que está todavía en su fase de inicio, pero cuyo desarrollo en profundidad está programado para un futuro inmediato.

${ }^{34}$ Eduardo Carrero Santamaría, "El claustro funerario en el medievo o los requisitos de una arquitectura de uso cementerial" , Liño, Revista anual de historia del arte, n० 12 (2006): 31-43.

35 Además de la presencia de los arcosolios, hechos como la denominación de la panda oeste del claustro como carnero reservado para los sacerdotes, confirman su finalidad funeraria. Eduardo Cristóbal Villanueva, Informe arqueológico preliminar sobre los arcosolios y sepulcros del claustro de la iglesia de Santa María la Real, en Sasamón (Burgos) (Burgos: Junta de Castilla y León, 1996), 16.

36 Si bien son muy similares a los que pueden encontrarse en otros claustros como el de San Esteban de Burgos, cuya construcción data también del siglo XIV y responde a esa misma concepción cementerial. Por desgracia, este claustro ha perdido sus tracerías.

37 María Jesús Gómez Bárcena, Escultura gótica funeraria en Burgos (Burgos: Diputación de Burgos, 1988), 19-20.

38 Pablo Ordás Díaz, "El claustro gótico en el reino de León: espacios, destinos e imágenes" (Tesis doctoral inédita, Universidade de Santiago de Compostela, 2017).

39 Transcripción de la autora. Para otra versión véase Cristóbal Villanueva, Informe arqueológico preliminar, 22.

${ }^{40} \mathrm{Si}$ bien es cierto que según la inscripción de la lauda esta debería formar parte del arcosolio de una capilla -de- dicada a San Francisco-, de la que hoy no queda constancia alguna, esta pudo haber formado parte del claustro en época medieval y haber sido alterada en época moderna o durante alguna de las sucesivas destrucciones y reformas que se han llevado a cabo en este espacio. Por el momento resulta imposible ir más allá de la hipótesis con respecto a esta cuestión.

${ }^{41}$ Cristóbal Villanueva, Informe arqueológico preliminar, 26-27.

42 Rilova Pérez y Simón Rey, Sasamón, 119-120.

43 Francisco Cerdá y Rico, ed. lit., Crónica de D. Alfonso el onceno de este nombre, de los reyes que reinaron en Castilla y en León (Madrid: Imprenta de D. Antonio de Sancha, Madrid, 1787), t. I, 5 .

${ }^{44}$ Antonio Benavides, ed. lit., Memorias de don Fernando IV de Castilla (Madrid: Real Academia de la Historia, 1860), t. I, 203.

45 Esther González Crespo, Colección documental de Alfonso XI: diplomas reales conservados en el Archivo Histórico Nacional (Madrid: Universidad Complutense, 1985), 97.

${ }^{46}$ Ibídem, 224.

47 Susana Guijarro González, "Religiosidad y muerte en el Burgos medieval (siglos XIII-XIV)", Codex Aquilarensis, $n^{\circ} 22$ (2006): 47

48 Esther González Crespo, "Un documento para el estudio de la Audiencia Real en el reinado de Alfonso XI", En la España medieval, n 4 (1984): 399.

49 Jorge Díaz Ibáñez, "La Iglesia de Castilla y León y el papado de Aviñon. Súplicas beneficiales, prosopografía y clientelismo eclesiástico en época de Urbano V", en El Reino de León en la Edad Media, ed. Manuel Lucas Álvarez (León, Centro de Estudios e Investigación "San Isidoro", 2003), vol. X, 491

${ }^{50}$ Henry Kelly, Canon law and the archpriest of Hita (Binghamton, Center for Medieval \& Early Renaissance Studies, 1984), 118: Juan Rodríguez de Sasamón, clérigo y familiar del Rey Alfonso de Castilla y León, porcionero y capellán en la iglesia de San Cosme y San Damián de Covarrubias en la Diócesis de Burgos, recibe en 1338 una canonjía en la iglesia de Santa María la Mayor, Valladolid (traducción de la autora).

51 Carlos Reglero de la Fuente, "La iglesia catedral de Palencia en el siglo XIV (1313-1397): crisis y reformas", Edad Media, Revista de Historia, 7 (2005-2006): 141.

52 Matías Sangrador Vítores, Historia de la muy noble y leal ciudad de Valladolid desde su más remota antigüedad hasta la muerte de Fernando VII (1851-1854) (Valladolid: Imprenta de D. M. Aparicio, Valladolid, 1854), 82.

53 Guijarro González, "Religiosidad y muerte", 59.

${ }^{54}$ Karge, La catedral de Burgos, 257.

55 El diseño de estos soportes guarda una gran similitud con el de los arranques de esa segunda puerta de acceso al claustro abierta en el siglo $X V I$. En consecuencia, se presenta como plausible la posibilidad de que durante esa campaña del siglo XVI no sólo las bóvedas, las ménsulas y las puertas fuesen modificadas sino también las basas de las columnas que sustentan la tracería de los ventanales. Una cicatriz que parece recorrer el arranque de todos estos soportes podría entenderse como la confirmación de este hecho. Es más, el arco de uno de los nichos de la panda occidental arranca sobre unas molduras -claramente encastradas a posteriorique recuerdan en gran medida a un modelo de soportes más simple utilizado en el tránsito del siglo XIII al XIV y que recuerdan a los de la catedral de Pamplona. Quizá no sería del todo descabellado pensar en la reutilización de uno de ellos como elemento decorativo de un arcosolio tras haber sido depuestos de su emplazamiento original en el siglo XVI.

56 Karge, La catedral de Burgos, 158.

57 Ibídem, 258. Los capiteles del claustro de Sasamón parecen mostrar rasgos estilísticos propios de finales del siglo XIII, si bien es cierto que muchos de ellos -especialmente los de la panda oeste- muestran señales de haber sido retocados. Un estudio detallado de los mismos excedería los límites de este trabajo.

58 Ibídem, 109-110. 
${ }^{59}$ Libro de Privilegios Reales concedidos a Sasamón. Archivo Diocesano de Burgos, armario 43, sig. 11, s.p. Incluye las confirmaciones de privilegios desde la de Sancho IV en 1284 (que hace referencia a los de Alfonso X, Fernando III y Alfonso VIII, pero no las incluye) hasta la de Felipe $V$ en 1718. Por otro lado, es importante citar a Luciano Huidobro y Serna, "Privilegios reales concedidos a Sasamón", Boletín de la Institución Fernán González, año XXXV, no 135 (segundo trimestre de 1956): 101-112. Este artículo es una trascripción del otro cuaderno de privilegios reales que se ha conservado y que lleva como título Confirmación al Concejo y hombres buenos de la villa de Sasamón de un privilegio que contiene ciertas exenciones $y$ franquezas. En él se incluyen las confirmaciones ya citadas $y$, a mayores, las de Fernando VI el 18 de enero de 1748, Carlos III el 7 de diciembre de 1761, Carlos IV el 28 de abril de 1790 y Fernando VII el 7 de diciembre de 1814. Tengo constancia de que en el Archivo General de Simancas también se conserva cierta documentación al respecto que todavía no he podido consultar.

${ }^{60}$ Ibídem. Dado en Burgos el 4 de diciembre de 1288 .

${ }^{61}$ Ibídem. Dado en Alcalá de Henares el 20 de diciembre de 1294.

62 Ibídem. Dado Medina del Campo en el 15 de mayo de 1302 .

63 Ibídem. Dado en Medina del Campo el 5 de septiembre de 1304 .

${ }^{64}$ Quien además añade otro privilegio: $E$ por fazer mas bien e mas merced a los del dicho lugar de santa maria de sasornon e porque la dicha obra esta comenzada se pueda mejor e mas ama e mas conplidamente acabar a servicio de Dios e de santa maria e por quanto nos fuernos ofrecido a la dicha yglesia de santa maria esrandoen peligro de muerte e Dios por m'ego de la gloriosa virgen santa manil su madre nos escapo de la muerte e fiamos en ella que nosfara mucha mas mereed cabo adelante damosles e otorgamosles e fazemos la merçed de todos los terminos de maçurrero de caraueo aldeas que fueron e son agora yermas e damosles e fazemos la merced de todos los términos dichos por suyos e libres e quitos por juro de here dad para siempre jamas sin rnartiniega e sin otro tributo alguno.

${ }^{65}$ Así lo hace constar el Becerro de las Behetrías: Al Rey non dauan monedas nin seruiços nin martiniega por rrazon que earn preuilligiados e que ge lo quitaran los rreyes por rrazon que fiziesen seruiço a la iglesia del dicho lugar en sacar canto e fazer la obra de la dicha eglesia e para los onrramentos della. Gonzalo Martínez Díez, ed., Becerro de las Behetrías, (León: Centro de Estudios e Investigación "San Isidoro", 1981), 250.

${ }^{66}$ Ya en 1904 el arquitecto e historiador Vicente Lampérez ("La iglesia de Santa María en Sasamón", 270) se preguntaba: ¿Mas que extraña importancia tuvo Sasamón para que en la centuria decimotercera, larguísimo tiempo después de haber desaparecido la sede, se elevase allí una iglesia con vuelos de verdadera y espléndida catedral, dotada y favorecida más tarde por Alfonso XI, Enrique II, Juan I, Juan II y Enrique III?

${ }^{67}$ Clara Fernández-Ladreda Aguadé, "El claustro y dependencias canonicales de la catedral de Pamplona: arqui- tectura y escultura", en Arte Gótico en Navarra, dir. Clara Fernández-Ladreda (Navarra: Dirección General de CulturaInstitución Príncipe de Viana, 2015), 186. El claustro de Pamplona toma a su vez como modelo al claustro de la catedral de Burgos en muchos aspectos.

68 Ibídem, 166.

69 Estos arcos, al igual que en Sasamón, están sustentados por finas columnillas que descansan sobre esbeltas basas apoyadas en un zócalo. Sin embargo, si bien hacia el exterior del patio el de Pamplona parece similar a los dos claustros burgaleses, en el interior la composición es ligeramente diferente. Las columnas que componen los pilares de los muros de las ventanas no arrancan desde el suelo, sino desde un nivel superior, a la altura del zócalo sobre el que se levantan los ventanales. Así, en lugar de las columnas corridas desde la base que en Sasamón y Burgos marcaban los arranques de los pilares diferenciándolos del de las columnillas que dividen las lancetas, en Pamplona todas arrancan a una misma altura. Sólo a cada uno de los pilares se adosa una especie de basamento en la parte inferior, moldura que en realidad no parece cumplir ninguna función estructural.

${ }^{70}$ Fernández-Ladreda, "El claustro y dependencias canonicales", 173.

71 Carlos Martínez Álava, "Arquitectura: parroquias, santuarios y monasterios", en Arte Gótico en Navarra, dir. Clara Fernández-Ladreda (Navarra: Dirección General de Cultura-Institución Príncipe de Viana, 2015), 297. 
Tracerías olvidadas: el claustro gótico de Santa María de Sasamón

\section{REFERENCIAS}

\section{Fuentes inéditas}

Libro de Fábrica y cuentas de la iglesia de Sasamón: 1789-1850. Archivo Diocesano de Burgos, armario 43, sig. 8, s.p.

Libro de Privilegios Reales concedidos a Sasamón. Archivo Diocesano de Burgos, armario 43, sig. 11, s.p.

Documentación relativa al proyecto de restauración de la colegiata de Santa María de Sasamón llevada a cabo por Marcos Rico Santamaría. Abril de 1961. Archivo General de la Administración, p.d.t. sig. Carpeta 52/4287.

\section{Bibliografía}

Ara Gil, Julia. 1995. "Escultura." In Historia del arte de Castilla y León, t. III. Arte Gótico, 219329. Valladolid: Junta de Castilla y León, Consejería de Cultura y Turismo.

Benavides, Antonio, ed. lit. 1860. Memorias de don Fernando IV de Castilla. Madrid: Real Academia de la Historia.

Carrero Santamaría, Eduardo. 2006. “El claustro funerario en el medievo o los requisitos de una arquitectura de uso cementerial." Liño, Revista anual de historia del arte 12: 31-43.

Carrero Santamaría, Eduardo. 2016. "Compostela, pauta y evocación en el Pórtico del Paraíso de la catedral de Ourense." In Modelo, copia y evocación en el románico hispano, coordinado por Pedro Huerta Huerta, 81-109. Palencia: Fundación Santa María la Real del Patrimonio histórico.

Cerdá y Rico, Francisco, ed. lit. 1787. Crónica de $D$. Alfonso el onceno de este nombre, de los reyes que reinaron en Castilla y en León. Madrid: Imprenta de D. Antonio de Sancha.

Cristóbal Villanueva, Eduardo. 1996. Informe arqueológico preliminar sobre los arcosolios y sepulcros del claustro de la iglesia de Santa María la Real, en Sasamón (Burgos). Burgos: Junta de Castilla y León, Dirección general de patrimonio y promoción cultura.

Cristóbal Villanueva, Eduardo. 1997. Informe técnico sobre la intervención arqueológica de urgencia realizada en el claustro de Santa María la Real de Sasamón (Burgos). Burgos: Junta de Castilla y León, Dirección general de patrimonio y promoción cultura.

De la C., S. 1884. "Segisamún ayer: Sasamón hoy." Revista Contemporánea, año X, tomo XLIX (Enero-Febrero): 385-404.

Díaz Ibáñez, Jorge. 2003. "La Iglesia de Castilla y León y el papado de Aviñon. Súplicas beneficiales, prosopografía y clientelismo eclesiástico en época de Urbano V." In El Reino de León en la Edad Media, edited by Manuel Lucas Álvarez, vol. X, 469-715. León: Centro de Estudios e Investigación "San Isidoro".

Fernández-Ladreda, Clara. 2015. “El claustro y dependencias canonicales de la catedral de Pamplona: arquitectura y escultura." In Arte Gótico en Navarra, dir. Clara Fernández-Ladreda Aguadé, 157-250. Navarra: Dirección General de Cultura-Institución Príncipe de Viana.

García de Quevedo y Concellón, Eloy. 1899. “Excursiones por la provincia de Burgos: conferencia dada en el Ateneo de Madrid el 17 de marzo de 1899." Sociedad Española de Excursiones, año VII, nº 82 (Diciembre): 205-206.

Gómez Bárcena, María Jesús. 1988. Escultura gótica funeraria en Burgos. Burgos: Diputación de Burgos.

González Crespo, Esther. 1984. “Un documento para el estudio de la Audiencia Real en el reinado de Alfonso XI." En la España medieval 4: 391-412.

González Crespo, Esther. 1985. Colección documental de Alfonso XI: diplomas reales conservados en el Archivo Histórico Nacional. Madrid: Universidad Complutense.

Guijarro González, Susana. 2006. "Religiosidad y muerte en el Burgos medieval (siglos XIII-XIV)". Codex Aquilarensis, n 22: 42-73.

Guijarro González, Susana. 2016. El bien façer, el buen morir y la remembranza en la sociedad medieval burgalesa (siglos XIII-XV). Santander: Editorial de la Universidad de Cantabria.

Huidobro y Serna, Luciano. 1912. "Sasamón: villa de arte." Boletín de la Sociedad Castellana de 
Excursiones, t. V (1911-1912): 17-18; 38-40; 59-64; 113-120.

Huidobro y Serna, Luciano. 1956. "Privilegios reales concedidos a Sasamón." Boletín de la Institución Fernán González, año XXXV, no. 135 (2 trim.): 101-112.

Karge, Henrik. 1995. La catedral de Burgos y la arquitectura gótica del siglo XIII en Francia y España. Valladolid: Junta de Castilla y León.

Karge, Henrik. 2004. "La arquitectura de la catedral de León en el contexto del gótico europeo." In Actas de Congreso internacional "La Cateral de León en la Edad Media", edited by Gerardo Boto Varela, $M^{a}$ Victoria Herráez Ortega y Joaquín Yarza Luaces, 113-144. León: Universidad de León.

Kelly, Henry. 1984. Canon law and the archpriest of Hita. Binghamton: Center for Medieval \& Early Renaissance Studies.

Lampérez y Romea, Vicente. 1904. "La iglesia de Santa María en Sasamón (Burgos)." La ilustración española y americana, año XLVIII, no. XLI: 267-270.

López Mata, Teófilo. 1953. "Santa María de Sasamón." Boletín de la Institución Fernán González 123, año 32 (2 trim.): 551-553.

Martínez Álava, Carlos. "Arquitectura: parroquias, santuarios y monasterios." In Arte Gótico en Navarra, dir. Clara Fernández-Ladreda Aguadé, 251-307. Navarra: Dirección General de Cultura-Institución Príncipe de Viana.

Martínez Burgos, Matías. 1955. “En torno a la catedral de Burgos." Boletín de la Institución Fernán González, año 34, no. 130 (1er trim.): 433-459.

Martínez Díez, Gonzalo, ed. 1981. Becerro de las Behetrías. León: Centro de Estudios e Investigación "San Isidoro".

Neubecker, Ottfried. 1977. Le grand livre de I'héraldique. París: Elsevier Séquoia.

Ordás Díaz, Pablo. 2017. "El claustro gótico en el reino de León: espacios, destinos e imágenes."
Tesis doctoral inédita, Universidade de Santiago de Compostela.

Orive Salazar, Alejandro. 1969. Sasamón: ciudad milenaria y artística. Burgos: Diputación Provincial.

Oroño Díaz, Andrés, and Miguel Ángel López Miguel. 1992. Santa María la Real de Sasamón (Burgos): estudio técnico. Burgos: Junta de Castilla y León, Dirección general de patrimonio y promoción cultural.

Oroño Díaz Andrés, and Miguel Ángel López Miguel. 1998. Memoria final de la restauración del claustro de la colegiata de Santa María de Sasamón (Burgos). Burgos: Junta de Castilla y León, Dirección general de patrimonio y promoción cultura.

Pardo de Guevara y Valdés, Eduardo. 2012. De linajes, parentelas y grupos de poder. Aportaciones a la historia social de la nobleza bajomedieval gallega. Madrid: Fundación cultural de la nobleza española.

Reglero de la Fuente, Carlos. 2006. "La iglesia catedral de Palencia en el siglo XIV (1313-1397): crisis y reformas." Edad Media, Revista de Historia 7 (2005-2006): 121-158.

Rilova Pérez, Isaac, and Jesús Simón Rey. 2005. Sasamón: Historia y guía artística. Burgos: Editorial Dossoles.

Sánchez Ameijeiras, Rocío. 2001. "La portada del Sarmental de la Catedral de Burgos. Fuentes y Fortuna." Materia 1, L'estil: 161-198.

Sangrador Vítores, Matías. 1854. Historia de la muy noble y leal ciudad de Valladolid desde su más remota antigüedad hasta la muerte de Fernando VII (1851-1854). Valladolid: Imprenta de D. M. Aparicio.

Welander, Christopher. 1990. "The Architecture of the Cloister of Burgos Cathedral." In Medieval Architecture and Its Intellectual Context. Studies in Honour of Peter Kidson, edited by Eric Fernie and Paul Crossley, 159-169. London: The Hambledon Press. 
